\title{
An economic study of small scale cattle fattening enterprise of Rajbari district
}

\author{
P. K. Sarma and J. U. Ahmed ${ }^{1}$ \\ Bangladesh Agricultural University Research System (BAURES), Bangladesh Agricultural University, Mymensingh- \\ 2202, Bangladesh, E-mail: paresh_ks@yahoo.com, sharmapk73@gmail.com and ${ }^{1}$ Department of Agricultural \\ Economics, Sylhet Agricultural University, Sylhet
}

\begin{abstract}
The small scale cattle fattening enterprise is represents an important component of the agribusiness sector of the economy with great economic, income, poverty reduction and social implications. A large number of farmers involved in cattle fattening just before 3 or 4 months of Eid-ul-Azha (Muslim festival), when they sell the animals with profitable prices. Cattle fattening for beef production have become an important business of the small farmers in Bangladesh. This study examined the profitability as well as operational economics efficiency of cattle fattening enterprise of Rajbari District. Data used to achieve this objective was obtained from 120 nomadic farmers, which were randomly selected using a multi-stage sampling procedure. Data were generated using a survey schedule as well as direct observation (cost-route method). Descriptive statistics, economics analysis as well as operational efficiency index were used to analyze the data. Results showed that small scale cattle fattening enterprise were profitable and flexible. A net enterprise income of BDT 5559 per cattle was realized by an average enterprise in study area. It was also shown that operational efficiency was not generally high among the entrepreneur. Based on these results, the study advised less efficient entrepreneurs to adopt the practices of the efficient ones in order to make the enterprise more profitable. The study shows that small scale cattle fattening enterprise is profitable due to agribusiness context. Farmers used three years old cattle for beef fattening. Cattle fattening period is 4.5 months in rural study areas of Rajbari district in Bangladesh.
\end{abstract}

Keywords: Economic efficiency, Cattle farming, Profitability

\section{Introduction}

Bangladesh is a low-lying densely populated country of more than 150 million people, $75 \%$ of who live in rural areas; rural poverty rate is $63 \%$, of which $36 \%$ are extreme poor (Hodson R. 2006). Livestock are an integral component of agriculture in the study area and make multifaceted contributions to the growth and development in the agricultural sectors. Small scale cattle fattening is an important avenue for income generation for mainly subsistence farmers in Rajbari District. Cattle farming are an important subsidiary to agriculture and playing a significant role in rural economy in Bangladesh (Hashem et. al. 1999). The livestock resources of Bangladesh are mainly based on cattle, goat, sheep, buffalo, and poultry. Although cattle concentration per unit area is high, their productivity is low mainly due to inadequate feed supply and low genetic potentiality ( Pandit 2005). As a result their growth performance is very poor. During the holy Eid-Al Azha festival. Muslims always go for Kurbani (sacrificing slaughtered livestock). Animals including cows, goats, camels and sheep are slaughtered each year to mark the festival. The meat is then distributed, with one-third meat by the immediate family and relatives, one-third given away to friends, and one-third donated to the poor. Bangladesh has the world's third largest Muslim-majority population. Bangladeshi Muslims celebrate the Eid in every year. About 1.8 million cattle are sacrificed at this time each year (Sujan et. al. 2011). Cattle fattening for beef production have become an important business of the small farmers in Bangladesh. In some areas of Bangladesh a small scale commercial cattle fattening program has already been started. Straw is the important crop residue; contribute the major portion of the fibrous part of the diet of the beef cattle. Rice straw is the basal feed for ruminants with low nutritive value and low digestibility. Farmers use rice straw of traditional varieties, green grass, sugarcane tops, wheat and rice bran, molasses, pulse bran and locally available resources such as pumpkin, carrot, banana, vegetable by products, rice gruel, boiled rice bran, oil cakes etc for beef fattening. The chemical treatment of straw is the most effective and economic method to improving the quality. Straw is mainly treated with urea and molasses and in some cases chemical treatment also done by the farmers. Urea molasses straw treatment in beef cattle resulted higher body weight, dressing percentage and also in better carcass quality than untreated straw. 
The acute shortage of feeds and fodder has long been identified as a serious constraint to optimum livestock production in Bangladesh (Saadullah.1995). It is an ancient, vital and renewable natural resource. Increase socio-economic conditions of Cattle farmer; create employment opportunities for rural unemployed and landless people. Livestock is contributing up to 80 percent of agricultural GDP; 600 million rural poor people rely on livestock for their livelihoods in our country. Livestock not only sources of food and income but also the main three pathway of poverty (1) securing the assets of the poor, (2) improving smallholder and pastoral productivity and (3) increasing market participation by the poor. A large number of farmers involved in bull fattening just before 3 or 4 months of Eid-Ul-Azha (Muslim festival), when they sell the animals with profitable prices. A cattle farming is a way of rearing cattle for profitable production of meat. Cattle fattening package is a four-steps rearing programme of male and/or infertile female emaciated cattle for harvesting their compensatory growth within a period of 60 to 120 days. Collection of animals considering their body characteristics followed by deworming and feeding cost effectively up to a profitable rate of live weight gain and marketing them readily are the four major factors to make the fattening package profitable. It is an easy and profitable system of cattle rearing to alleviate poverty, unemployment and generate income both for the rural people. Therefore, the present study has been undertaken specially'

1. To identify the socioeconomic characteristics of cattle fattening farmers of the study areas.

2. To determinate of the economics efficiency of small scale cattle fattening farms in the study area.

\section{Materials and Methods}

The present study was conducted at three Upazilas of Rajbari district viz, Pangsha, Rajbari sadar and Baliakandi. Data were collected during September to November 2010. Covering 120 small scale cattle fattening farm. Each upazila equally selected 40 farms by using purposive sampling technique and survey questionnaire. Collected data were organized structured and analyzed in accordance of the objectives set for the study by using different model, tabular method as well as using simple descriptive statistical tools are techniques by using Microsoft Excel and SPSS program.

Measurement of Costs and Returns: The cost benefit analysis is determinants of economic analysis was modeled in terms of direct, indirect cost and returning variables and other factors considering of cattle fattening farm in the study area. The economic analyzed the determinants;

$$
\begin{aligned}
& \text { TC }=\text { DC }+ \text { IC }(\text { Total Cost }=\text { Directcost }+ \text { Indirect Cost }) \\
& \text { TR }=\text { Total Return }=\text { DR }+ \text { IR }=\text { Direct Return }+ \text { Indircet Return } \\
& \text { NM(Net Margin })=\text { TR }- \text { TC }=\text { Total Return }- \text { Total Cost }
\end{aligned}
$$

Measurement of Economic Efficiency: Economic efficiency is a term typically used in microeconomics when discussing product. It is the study of cattle fattening entrepreneur maximizes the use of their socioeconomic inputs so as to maximize the production of goods and services. Production of a unit of good is considered to be economically efficient when that unit of good is produced at the lowest possible cost. In the present study, the determinants of economic efficiency were modeled in terms of socioeconomics variables of the cattle fattening farmers and other factors. The economic efficiency in the model was simultaneously estimated with their determinants (Okoye et.al. 2007);

\section{Economics Efficiency:}

$E i=\alpha_{0}+\beta_{1} X_{1}+\beta_{2} X_{2}+\beta_{3} X_{3}+\beta_{4} X_{4}+\beta_{5} x_{5}+\beta_{6} X_{6}+\beta_{7} X_{7}+\beta_{8} X_{8}+\beta_{9} X_{9}------(1)$

Where

Ei is the economic efficiency of $\mathrm{i}^{\text {th }}$ cattle fattening farm.

$\alpha_{0}$ is the intercept

$\mathrm{X}_{1}=$ Farmer sex (Male or Female)

$\mathrm{X}_{3}=$ Cattle fattening farmers educational level.

$X_{5}=$ Farm size (Base on number of cattle)

$\mathrm{X}_{7}=$ Capital use of farming of cattle fattening

$\mathrm{X}_{9}=$ Extensional visit

and $\beta_{1}, \beta_{2}, \beta_{3}, \beta_{4}, \beta_{5}, \beta_{6}, \beta_{7}, \beta_{8}$ and $\beta_{9}$ are the regression parameters to be estimated. 


\section{Results and Discussion}

Socioeconomic Characteristics of Cattle fattening farmers of the study areas: Table 1 shows the socioeconomic characteristics of the respondents. From the data generated from the field survey, and the frequency distribution of the respondents according to sex, age, education, farming experience, farm size and household size. Seventy four percent of the respondents were females while $31 \%$ were males. This implies that women constitute a greater percentage of those involved in cattle farm production in the study area. About 50 percent of the farmers comprise those that have attained the age of fifty years and above, a farmer's age affects her efficiency in performing farm management decisions. A cattle farming is less laborious than other root and tuber crops and dose not require a lot of physical strength. Forty five percent of the farmers had no formal education, while only $17.5 \%$ attended primary school. Educated farmers are expected to be more receptive to improved farming techniques (Okoye et. al. 2007). About $12.5 \%$ of the respondents had less than 5 years of farming experience while $87.5 \%$ had more than 5 years of farming experience.

Table 1. Distribution of Cattle Farmers according to their sex, age, education, farmer experience, farm size and household size

\begin{tabular}{|c|c|c|}
\hline Variable & Frequency & Percentage (\%) \\
\hline $\begin{array}{l}\text { Sex } \\
\text { Male } \\
\text { Female } \\
\text { Total }\end{array}$ & $\begin{array}{c}31 \\
89 \\
120\end{array}$ & $\begin{array}{c}25.83 \\
74.20 \\
100\end{array}$ \\
\hline Age(In year) & Frequency & Percentage (\%) \\
\hline $\begin{array}{l}24-29 \\
30-35 \\
36-40 \\
41-45 \\
46-50 \\
>50 \\
\text { Total } \\
\text { Mean } \\
\end{array}$ & $\begin{array}{c}5 \\
6 \\
11 \\
14 \\
17 \\
67 \\
120 \\
50 \mathrm{yrs} \\
\end{array}$ & $\begin{array}{c}4.16 \\
5.00 \\
9.17 \\
11.17 \\
14.17 \\
55.83 \\
100\end{array}$ \\
\hline Educational level & Frequency & Percentage (\%) \\
\hline $\begin{array}{l}\text { No Schooling } \\
\text { Primary } \\
\text { Secondary } \\
\text { Tertiary } \\
\text { Total } \\
\text { Mean } \\
\end{array}$ & $\begin{array}{c}54 \\
21 \\
31 \\
14 \\
120 \\
6.3 \mathrm{yrs} \\
\end{array}$ & $\begin{array}{c}45.00 \\
17.50 \\
25.83 \\
11.70 \\
100\end{array}$ \\
\hline Farming Experience(Year) & Frequency & Percentage (\%) \\
\hline $\begin{array}{l}<5 \\
5-10 \\
11-16 \\
17-22 \\
>22 \\
\text { Total } \\
\text { Mean }\end{array}$ & $\begin{array}{c}15 \\
48 \\
17 \\
20 \\
20 \\
120 \\
13.35 \text { yrs } \\
\end{array}$ & $\begin{array}{c}12.50 \\
40.00 \\
14.17 \\
16.60 \\
16.60 \\
100.00\end{array}$ \\
\hline Farm size (ha.) & Frequency & Percentage (\%) \\
\hline $\begin{array}{l}.01-0.05 \\
.0 .06-.10 \\
0.20-0.60 \\
0.70-1.00 \\
1 \text { ha and Above } \\
\text { Total } \\
\text { Mean }\end{array}$ & $\begin{array}{c}54 \\
3 \\
52 \\
9 \\
2 \\
120 \\
.027 \text { ha }\end{array}$ & $\begin{array}{c}45.00 \\
2.50 \\
43.20 \\
7.50 \\
1.70 \\
100\end{array}$ \\
\hline Household Size (Number) & Frequency & Percentage (\%) \\
\hline $\begin{array}{l}2-4 \\
5-7 \\
8-10 \\
11-13 \\
>10 \\
\text { Total } \\
\text { Mean } \\
\end{array}$ & $\begin{array}{c}2 \\
23 \\
7 \\
16 \\
72 \\
120 \\
12 \text { (Persons) } \\
\end{array}$ & $\begin{array}{c}1.67 \\
19.17 \\
5.83 \\
13.33 \\
60.00 \\
100.00\end{array}$ \\
\hline
\end{tabular}


The mean farming experience was $13 \%$ years farmers are therefore described as experienced and are expected to have higher efficiency. Forty eight percent of the respondents have cattle farmer holdings of less than 0.1 ha. This implies that cattle production in the study area is dominated by small scale production given the average farm size of $0.27 \%$ ha for the area. The data on table1 also depicts that a large parentage $(98 \%)$ of the respondents have household size of 5 persons and above while less than $2 \%$ have household size of less than 5 persons.

Costs and returns to the Cattle fattening enterprise: The costs incurring from cattle fattening were into main components as direct and indirect cost. Direct cost of cattle fattening comprised various variable costs such as cost of cattle, feeder, feed, healthcare services etc (Mulla,NI 1997). On the other hand indirect costs covered depreciation of interested of capital and equipment such as durable Drinkers, Spade, Bucket, Rakes, wage of labour etc. The significant contribution of cattle fattening activity as supplemental income source was obviously seen. Table 2 shows that on the average cost of cattle fattening is Tk 16316 and return Tk 21875 per cattle. After 3-4 months rearing of cattle through fattening technology, farmer obtained profit Tk 5559 per cattle. It implies that cattle fattening enterprise is profitable alternative income opportunities in rural areas. Most of the participating farms were satisfied with the supplemental net income earning from cattle fattening with short duration.

Table 2. Cost and return of cattle fattening per cattle in the study area

\begin{tabular}{|c|c|c|c|c|c|c|c|}
\hline \multicolumn{3}{|c|}{ Production Cost (BDT) } & \multirow{2}{*}{$\begin{array}{c}\text { Average } \\
\text { cost } \\
\text { (BDT) }\end{array}$} & \multicolumn{3}{|c|}{ Return (BDT) } & \multirow{2}{*}{$\begin{array}{c}\text { Average } \\
\text { Return } \\
\text { (BDT) }\end{array}$} \\
\hline Cost Items & $\begin{array}{c}<5 \\
\text { Cattle }\end{array}$ & $\begin{array}{l}>10 \\
\text { Cattle }\end{array}$ & & Return Items & $<5$ Cattle & $\begin{array}{l}>10 \\
\text { Cattle }\end{array}$ & \\
\hline Direct Cost: & & & & Direct Return: & & & \\
\hline $\begin{array}{l}\text { Purchase of Cattle before } \\
\text { fattening }\end{array}$ & 45810 & 89620 & 9029 & & & & \\
\hline Purchased feed & 17360 & 31670 & 3269 & $\begin{array}{l}\text { Selling price of } \\
\text { fattened Cattle }\end{array}$ & 99673 & 199240 & 19928 \\
\hline vet\& medicine & 2875 & 4137 & 467 & $\begin{array}{l}\text { Sales of } \\
\text { manure }\end{array}$ & 6914 & 11379 & 1220 \\
\hline Salt/Potash & 750 & 1278 & 135 & $\begin{array}{l}\text { By product } \\
\text { sales }\end{array}$ & 3250 & 7680 & 728 \\
\hline Fertilizer & 335 & 746 & 72 & & & & \\
\hline Rent & 1355 & 2689 & 270 & & & & \\
\hline \multicolumn{8}{|l|}{ seed/plants } \\
\hline Indirect Cost: & & & & Indirect Return & & & \\
\hline Interest on Capital & 5726 & 11202 & 1129 & Cow/Bulk Sell & & & \\
\hline Labor & 7890 & 17780 & 1711 & & & & \\
\hline Depreciation & 1145 & 2370 & 234 & & & & \\
\hline Total Cost $=$ & 83246 & 161492 & & Total Return= & 109837 & 31785 & \\
\hline \multicolumn{3}{|l|}{ Average Cost $=$} & 16316 & \multirow{2}{*}{\multicolumn{3}{|c|}{ Average Return $=$}} & 21875 \\
\hline Net Margin & & & & & & & 5559 \\
\hline
\end{tabular}

Source: Field survey data 2010

Economic efficiency: Table 3 shows the result of the factors influencing economic efficiency of cattle fattening farming in the study area. The coefficient of age, education experience and farm size were highly significant at $1.0 \%$ level of probability. This implies that age, education and farm size had a negative relationship with economics efficiency among the farmers sampled. The older a farmer becomes, the more he or she is unable to combine his or her resources in an optional manner given the available technology. Most of the farmers had little or no education which implies that education is not costless but requires investment. Lack of education might not be regarded as a factor causing inefficiency. 
Only if it is costless could we say that it would contribute to improvement in efficiency. This goes against the findings; the increasing year of formal education increases a farmer's level of allocative and technical efficiency which improved their economic efficiency.

Table 3. Determinants of Economic efficiency of Cattle fattening farming

\begin{tabular}{|l|c|c|c|c|}
\hline \multicolumn{1}{|c|}{ Variables } & Parameter & Coefficient & Standard Error & t-value \\
\hline Constant term & $\alpha_{0}$ & -1.9336 & 0.9670 & -1.9996 \\
\hline Farmers sex & $\mathrm{X}_{1}$ & -0.04456 & 0.0162 & -2.8211 \\
\hline Farmer age & $\mathrm{X}_{2}$ & -0.0895 & 0.0319 & -2.8064 \\
\hline Farmers educational level & $\mathrm{X}_{3}$ & 0.0235 & 0.0750 & 0.3133 \\
\hline Farming experience & $\mathrm{X}_{4}$ & 0.0146 & 0.0412 & 0.3563 \\
\hline Farm size & $\mathrm{X}_{5}$ & -5.1097 & 1.0561 & -4.8383 \\
\hline Household size & $\mathrm{X}_{6}$ & 0.0533 & 0.0220 & 2.4258 \\
\hline Capital use for farming & $\mathrm{X}_{7}$ & 1.0309 & 0.4036 & 2.5542 \\
\hline Use of fertilizer & $\mathrm{X}_{8}$ & 1.0813 & 0.4730 & 2.5130 \\
\hline Extensional visit & $\mathrm{X}_{9}$ & 0.0219 & 0.063 & 0.3213 \\
\hline
\end{tabular}

Source: Field survey data 2010

Extension visit, family size and credit access were positively signed but were not significant. Fertilizer use was positively signed and significant at $5.0 \%$ level of probability. This implies that farmers who use fertilizer were economically efficient. Membership of cooperatives was negatively signed but not significant even at $10 \%$ level of probability.

\section{Conclusion and Recommendation}

Cattle fattening enterprise is a potential and effective option for poor and extreme poor and gained prominence as an important agribusiness sector of agriculture in Bangladesh. It gives the farmer year round work and provides him with extra income. In the study area, cattle fattening could play a vital role in poverty reduction, creation of self employment opportunities in rural areas and animal protein supply. The small scale cattle fattening enterprise is a profitable venture in the study area. The major findings and recommendation of the study could be summarized and presented as follow;

1. There were no competition between the cattle fattening activity and major crop production in using family labour and land resources. The major farm output like sugar cane and rice were not affected by the introduction of backyard cattle fattening operation.

2. Cattle fattening was able to additional income and generate the employment for farm household members, especially the unemployed family members like housewife and old persons. These enterprises increased the labour productivity and employment of family members in rural area.

3. The major constraint for the participating farm households to continue the cattle fattening by their own support or browning money with high interest rate from NGOs due to shortage of investment fund due to a relatively high investment cost of cattle fattening as compared to their annual income.

4. The important factors indirectly related to economic efficiency are age, education, farm size, farm experience and fertilizer use. These results call for policies aimed at encouraging new entrants especially the entrepreneur of cattle fattening farms.

5. Cattle fattening entrepreneur should be enlighten on how to access credit in order to increase their capital base to expand their scale of production.

6. Cattle farmer is a need to enlighten fatteners on the importance of weighting their animals at purchase and at regular interval until they are finally disposed.

7. To have effective agribusiness strategies that provides guidance to steer the agribusiness development process. Such support services and establishment policy and legislation mobilize stakeholders in the agribusiness of cattle fattening sector and deliver market driven agro-food products through an accreditation process.

8. To have dynamic public and private finance and investment programs that help to stimulate growth and expansion of the agribusiness of Cattle fattening sector of Bangladesh. 


\section{References}

Pandit, Arun. 2005. Efficiency of Dairy Cattle Markets in Central Alluvial Plains of West Bengal. Journal of Agril. Marketing Vol. (5-1): pp. 44-50.

Hashem, M.A.M., Moniruzzaman, S. Akhter and Hassain, M.M. 1999. "Cattle fattening by rural farmers in different district of Bangladesh" Bangladesh Journal of Animal Science;28(1-2); pp 81-88.

Hodson, R. 2006. "The Char Livelihood Programme, the story and strategy so far. CLP Secretariat, RDA Campus, Bogra.

Baset, M.A., Rahman, M.M., Islam, M.S., Ara, A., Kabir, A.S.M. 2003. Beef Cattle Production in Bangladesh- A Review. Online Journal of Biological Sciences Vol.3 (1) pp 8-25.

Mulla, NI. 1997. Marketing costs and Price Spread-Cattle Marketing in Haveri Cattle Market of Karnataka, Journal of Agril. Marketing. West Bengal, India XL. (2): pp 42-47.

Okoye, B,C., Okorji, E.C. and Asumugha, G.N. (2007);"Economic efficiency of small-holder Cocoyam farmers in Anambra State Nigeria. Agricultural Journal Vol.2. pp 535-542.

Sujan, O.F., Siddque, M.A.B. and Karim, M.F. 2011. "Study on cattle fattening practices of some selected areas of Rangpur district in Bangladesh" Bangladesh Research Publications Journal. Vol. 5(2). pp 125-132.

Saadullah, M. 1995. "Integrated farming system for rural poor (Livestock based)". Journal of Biological Sciences 3 (10): pp. 898-902. 